\title{
THE ANNUAL REPORTS AND FINANCIAL DECISIONS
}

\author{
Lecturer PhD Maria Berheci, „Alexandru Ioan Cuza” University of Iaşi, \\ e-mail:maria_lia24@yahoo.com
}

\begin{abstract}
Although one may say that the components of financial statements may be considered autonomous and independent elements, the whole accounting processing procedure ends with a set of financial statements that are closely interconnected from the information viewpoint. Therefore, the earnings are shown in the balance sheet, by themselves, however their stages are thoroughly described in the income statement. If we consider a company's cash account, it interconnects the balance sheet and the cash flow statements. The balance determines the amounts of available cash and their changes in time, however it does not account for the causes of these variations. The latter are actually the object of the cash flow statement. Also regarding the company's earnings, their main manifestations may be found in the balance sheet - accounting earnings and economic earnings - however an elaborate description, starting with the net earnings and going to the economic earnings, is to be found separately, as an equity capital statement. Our paper dwells on the interdependence of the components of financial statements and on its influence on financial decisions.
\end{abstract}

Keywords: financial statements, balance sheet, income statement, cash flow statement, decision.

JEL Codes: M41, M48

The financial communication process is vital in the economic life. Research carried out on the financial communication procedures of the first 100 largest industrial and trade company groups has shown that financial-accounting information is the main element of a company's financial communication policy ${ }^{1}$. Both the amount of information published and especially its quality are important, which has been continuously improving due to the harmonization of international accounting standards and which therefore enabled the companies to engage in an information competition with other companies operating at national or international level.

At the beginning, financial statements only allowed a better accounting data organization, their synthesis, and they were not involved in the economic decision-making process, as accounting was considered a mere tool used for company assets preservation ${ }^{2}$. The second half of the $20^{\text {th }}$ century witnessed the employment of accounting information in the decision-making process, as the users were becoming increasingly numerous, due to a higher company responsibility and involvement in the society.

Here are some of the most important roles of accounting related to its goals. Thus, accounting is supposed to measure and shape the company wealth (described mainly in the balance sheet) and the wealth acquired during the last financial year (described in the profit and loss account and in the equity capital statement). Another essential role played by accounting is meeting the shareholders' requirements, which means it allows them to have an idea of the work of the

\footnotetext{
${ }^{1}$ Negescu, M., D., Informația financiară - suport în luarea deciziilor (Financial Information - Support in Decision Making), in the Contabilitate şi informatică de gestiune (Accounting and Business Data Processing) Magazine, issue 9/2005, Academy of Economic Sciences, Bucharest, p. 54.

2 Dobroțeanu, L., Geneză şi viitor în contabilitate (Genesis and Future Prospects in Accounting), Economic Publishing, Bucharest, 2005, p. 223.
} 
company management. The third major role is especially related to the financial communication process.

Financial communication includes both a compulsory communication required under the law, and a voluntary financial-accounting information communication (for instance, forecasts is usually information communicated willingly and not required under the law). The purpose of financial communication is a better company image among the interested parties, sometimes to the detriment of accurate information. Just as ,a good product does not necessarily sell well”, a ,good (accurate) accounting does not necessarily sell well"3. Therefore, company managers and accounting professionals are real financial-accounting information traders. Although the purpose of financial communication is a positive perception by the financial-accounting information users, there are cases when the communication of information of an exaggerated optimism may make information recipients suspicious.

Ch. Hoarau ${ }^{4}$ attempts a synthesis of the goals of accounting and of its outcome, the financial statements:

* it is a company control tool;

* it is an evidence and justification means;

* it supports economic decisions;

* it is one of the national statistics and accounting sources;

* it is the grounds on which economic-financial diagnosis relies.

As a company control tool, accounting enables the interested parties to check the sharing of the company wealth, that is a proper dividend distribution to the shareholders, an accurate calculation of the taxes and fees owed to various public bodies, as well as the fulfillment of the contracts concluded by the company and various business partners. In other words, accounting serves as a law violation and fraud detection tool.

Since it is a record of transactions, accounting undoubtedly serves as evidence before a court of law, provided it is an honest and accurate accounting, which observes all the legal requirements in effect. An inaccurate accounting, for instance, cannot be used in case of a dispute. While enforcing the shareholders' rights and exercising company management, accounting provides to the shareholders information able to enable them to have control over the work of the company management, just as accounting is, for the company management, a justification means of their deeds and positions.

Once a distinction was made between company shareholders and professional managers, the $20^{\text {th }}$ century brought about an increasingly acute need of information for the decision-making process by shareholders and managers, and also by other users. Therefore, the information role of accounting is supported its internal and external decision-making purpose. The author above sees accounting as the backbone of financial information. According to the information in the financial statements, an investor should be able to make decisions related to investing in a certain company, to leaving a company, to increasing or decreasing his/her investment. Moreover, accounting information is an efficiency requirement of financial markets, as it contributes to a better resource distribution.

Another goal of accounting, maybe the most important, is related to the fact that it constitutes the support and grounds for the diagnosis of a company's economic and financial performance and risks, as well as for determining its value. As a result, and also as a cause of all these goals, accounting is also a social organization tool, providing the necessary trust in the company events and transactions, being standardized, regulated and controlled.

\footnotetext{
${ }^{3}$ Negescu, M., D., Informația financiară - suport în luarea deciziilor (Financial Information - Support in Decision Making), in the Contabilitate şi informatică de gestiune (Accounting and Business Data Processing) Magazine, issue 9/2005, Academy of Economic Sciences, Bucharest,p. 57.

${ }^{4}$ Hoarau, C., Comptabilité et management, Editions Foucher, Vanves, 2004, pp. 17-20.
} 
In order to serve these goals, the International Accounting Standards Board (IASB) state that the financial statements drafted in order to provide useful information for making economic decisions meet the common requirements of most of their users. They make economic decisions in order to ${ }^{5}$ :

- $\quad$ decide when to buy, when to keep and when to sell shares of their capital;

- $\quad$ assess the management skills or responsibility of the management;

- $\quad$ assess the entity's ability to remunerate the staff and to offer other benefits to its employees;

- $\quad$ assess the security that the entity is able to provide for the loans it was granted;

- $\quad$ determine tax-related policies;

- $\quad$ determine the profit and dividends to be distributed;

- $\quad$ provide and use statistical data on the national income;

- $\quad$ regulate company business.

These economic decisions are currently made based on financial statements drafted according to an accounting model relying on the recoverable acquisition cost and on the nominal financial capital preservation concept. Other models and concepts may serve better to the substantiation of the users' decisions, however there is currently no agreement on possible changes.

It is well-known that the information offer of the financial-accounting system should be reliable and consistent, that it should be structured according to homogeneous rules and principles and, at the same time, it should serve the interests of all the users involved. Thus, in Romania, further to the passing of the Decision of the Ministry of Public Finance no. 1752/2005, financial statements are in agreement with the provisions of the European Directives, especially as concerns their approach as synthesis documents, comprising a rather generous amount of information, and they are also useful to meet the users' increasing demand of information. Although the state is still a privileged accounting information user, we have to admit however that thanks to the changes enforced by the regulation mentioned above, accounting information becomes more reliable, and the communication role of accounting develops another dimension.

The researchers who studied the relation between the theory of communication and the theory of decision making, reached the conclusion that information in general is interesting for the user if it meets the following requirements ${ }^{6}$ : it diminishes the uncertainty of a future event and it facilitates decision making, it supports the development of a decision making model and it enhances feed-back.

The table below shows a synthesis of the decisions that may be made by the accounting information users, depending on their information needs.

Table no. 1

Possible decisions of accounting information users

\begin{tabular}{|c|c|c|}
\hline Group of users & Grounds of the information needs & Possible decisions \\
\hline $\begin{array}{l}\text { Shareholders (owners) } \\
-\quad \begin{array}{l}\text { proxy function } \\
\text { investment }\end{array} \\
\text { function }\end{array}$ & $\begin{array}{l}\text { Management performance monitoring } \\
\text { Work assessment }\end{array}$ & $\begin{array}{l}\text { Dismiss the managers } \\
\text { Sell, buy or keep the shares }\end{array}$ \\
\hline Creditors (banks) & $\begin{array}{l}\text { Finding the strengths and assessing the financial } \\
\text { stability of the entity }\end{array}$ & $\begin{array}{l}\text { Extend existing loans or refuse to } \\
\text { grant loans }\end{array}$ \\
\hline \begin{tabular}{lr}
\multicolumn{2}{l}{ Employees } \\
- & short-term \\
- & long-term \\
\end{tabular} & $\begin{array}{l}\text { Valuating the ability to remunerate the staff } \\
\text { Assessing the stability of the jobs offered }\end{array}$ & $\begin{array}{l}\text { Protests for better wages } \\
\text { Finding another job }\end{array}$ \\
\hline Clients & Assessing the future stability of the company & Conclusion of long-term contracts \\
\hline Suppliers & Valuating the financial strength of the company & Extension of business loans \\
\hline State & Measuring the taxable earnings and assessing the & Tax payment requirement and the \\
\hline
\end{tabular}

\footnotetext{
$5 * * *$ International Financial Reporting Standards, translated by CECCAR Publishing, Bucharest, 2007, p. 34.

${ }^{6}$ Minu, M., Op. cit., p.110 (according to Mack, 1971).
} 


\begin{tabular}{|l|l|l|}
\hline \multicolumn{1}{|c|}{ Group of users } & \multicolumn{1}{|c|}{ Grounds of the information needs } & \multicolumn{1}{c|}{ Possible decisions } \\
\hline Public in general & economic performance & $\begin{array}{l}\text { Aseed for new regulations } \\
\text { prosperity its contribution to the general }\end{array}$ \\
\hline Management & $\begin{array}{l}\text { Debby before the gouvernment and } \\
\text { corporations } \\
\text { earnings }\end{array}$ & $\begin{array}{l}\text { Dividend determination and tax } \\
\text { payment }\end{array}$ \\
\hline
\end{tabular}

Source: Flower, J., Global Financial Reporting, Palgrave, 2002, p. 68.

Accounting undoubtedly has a double role: information and decision-making support. Any decision made to solve a problem should focus on two variables: the assessment of the purpose or objective to be settled and the probability of decision carrying out ${ }^{7}$. We agree that, at company level, at the core of all possible decisions lies profit, which is more than a condition for the performance of an entity, it is a vital requirement for its survival. We know that a company is a system relying on human, material and financial means, designed to produce, and production is subjected to profit. The basic decisions needed to support this objective are easy to list: what, how, how much and at what cost should something be produced? We cannot say that some decisions are better than others, but we could speak of optimal decisions ${ }^{8}$, depending on the means employed and the potential evolution of the environment. If we consider the length of time, the amount of information and the decision-making level within an entity, we find three types of decisions: strategic, tactical and operational. Strategic decisions are made by the general company management, it has long-term consequences and the information required for its slow substantiation should be as varied as possible (for instance: investment decisions, financial restructuring, business changes, are all strategic decisions). Tactical and operational decisions may be substantiated more quickly, by the different entity departments and services, based on a smaller amount of information and they have medium- and short-term consequences (for example: budget calculation ia a tactical decision, and a decision related to the repairs performed on a damaged piece of equipment is an operational decision). Company efficiency and productivity relies on the promptness of operational decisions. However, it is not only the quantity of information that a proper decision making depends on, but also its quality. Consequently, the following should be the decision making stages: data knowledge and collection, data turning into information and the actual decision making.

The best use of an entity's financial resources requires a thorough analysis of all the strategic, economic and social components, followed by the substantiation of the economic decisions. Within the latter, financial decisions have the main place, as any type of decision sooner or later results into a financial flow. Some authors ${ }^{9}$ consider long-term financial decisions as a company's financial policy. This category includes: investment decisions, financing decisions and decisions related to dividend distribution. The latter are a communication means between the company and the market, being a signal for the earnings of the financial year in progress (the dividend distribution decision relies on the earnings of the previous financial year and also on the earnings of the first half of the financial year in progress). The same author includes in the category of short-term financial decisions the following: decisions on the management of the operation cycle, decisions on cash management, as well as decisions on the interest and exchange risks management. One should bear in mind that in practice there is no clear distinction between shortterm and long-term decisions.

\section{Instead of conclusions... .... a few comments on the accounting information market in our country}

\footnotetext{
${ }^{7}$ Spătaru, L., Analiza economico-financiară - instrument al managementului întreprinderilor (Economic-Financial Analysis - Company Management Tool), Economic Publishing, Bucharest, 2004, p. 34.

${ }^{8}$ Avare, Ph., ş.a., Gestiune şi analiză financiară (Financial Management and Analysis), Economic Publishing, Bucharest, 2002, p. 14 (translated and reviewed by: Niculescu, M., Dimitriu, M., Robu, V.)

${ }^{9}$ Stephany, E., Gestion financière, Economica, 2000, p.9.
} 
Although the accounting information market has had a positive evolution in our country, we cannot say that it works as it should. Our statement is supported by two major facts, namely: on the one hand, the state is still the main beneficiary of the accounting information, followed by the banks, as the bank financing system is still widely spread, consisting of stable and demanding accounting information users; and, on the other hand, the other external users seem to be unaware of their right to accounting information, or they do not trust the relevancy and reliability of the accounting information, and this accounts for their lack of reaction.

The conclusions of our study entitle us to state that the lack of transparency of the published information, which is subject to evenness and conservatism, is the cause for the information asymmetry between the providers and the users of accounting information. Moreover, considering that the state and the banks are still the privileged users of the information accounting in our country, the „Anglo-Saxon” information asymmetry (managers - shareholders) does not actually occur. And this would not necessarily be a bad thing, but the problem is the shareholders' weak reaction, probably caused by their poor economic knowledge, which makes them naive enough to accept the information provided by the managers as such, and by their imitating the behavior of other users. In addition to these causes, this lack of information strength of the national accounting information is certainly generated by the constant changes that occurred these last decades, changes designed to normalize the Romanian accounting system. Therefore the following statement applies here: nothing is more constant than change. Metonymically speaking, the choice of the best accounting option and its consistent application are equally important. Some changes were, of course, necessary, such as the changes incurred in the presentation of the accounting information offer, to the extent that the economic reality took the place of the purely legal aspect, which led to the expression: „deregulated financial statements” (drafted according to recommendations).

We know what the objective of financial statements is - the presentation of the information related to an economic entity, used for the users' decisions substantiation - their goal however may differ from case to case, caused by their nonconformity with the economic events which generated them, either because they were not correctly understood, or because of the diversity of the (social, economic, legal) factors influencing financial statement drafting, which will lead to different decisions. In other words, we found that the very diversity of the users' requests make it harder to satisfy their information needs. The conflict risks between the users of the accounting information may however be reduced by a high quality reference system, as well as by financial statements audits carried out by financial auditors.

\section{References}

1. Avare Ph., ş.a. - Gestiune şi analiză financiară (Financial Management and Analysis), Economic Publishing, Bucharest, 2002.

2. Dobroțeanu L. - Geneză şi viitor în contabilitate (Genesis and Future Prospects in Accounting), Economic Publishing, Bucharest, 2005.

3. Hoarau C., - Comptabilité et management, Editions Foucher, Vanves, 2004.

4. Negescu M. D. - Informația financiară - suport în luarea deciziilor (Financial Information - Support in Decision Making), in the Contabilitate şi informatică de gestiune (Accounting and Business Data Processing) Magazine, issue 9, Academy of Economic Sciences, Bucharest, 2005.

5. Spătaru L. - Analiza economico-financiară - instrument al managementului intreprinderilor (Economic-Financial Analysis - Company Management Tool), Economic Publishing, Bucharest, 2004.

6. Stephany E. - Gestion financière, Economica, Paris, 2000.

7. *** International Financial Reporting Standards, translated by CECCAR Publishing, Bucharest, 2007. 